\title{
Demyelination in experimental intraventricular neurocysticercosis
}

Desmielinização na neurocisticercose intraventricular experimental

Vania Beatriz Lopes MOURA', Analia Cirqueira MILHOMEM², Sarah Buzaim LIMA², Hidelberto MATOS-SILVA ${ }^{3}$, Denis Masashi SUGITA4 ${ }^{4}$, Marina Clare VINAUD', Ruy de Souza LINO-JÚNIOR'

\begin{abstract}
Neurocysticercosis (NCC) is classified as a neglected tropical disease, which affects mainly Latin America and Africa in spite of some reports in North America and Europe. NCC represents the cause of up to 30\% of the reported cases of epilepsy in endemic countries. The NCC injuries present direct relation to the development stage, location, and number of parasites as well as to the host immune response. This study aimed the characterization of the inflammatory response and tissue injuries by means of the analyses of the periventricular and parenchymatous demyelination through the experimental intraventricular NCC infection. Therefore, BALB/c mice were submitted to experimental NCC inoculation with Taenia crassiceps cysticerci. Their brains were removed at 7, 30, 60, and 90 days after the inoculation (DAI), and analyzed after staining with hematoxylin and eosin (HE), Luxol Fast Blue, and Nissl. It was possible to observe ventriculomegaly, inflammatory infiltration composed by polymorphonuclear and mononuclear cells, and foamy macrophages. The presence of inflammatory cells was associated with neurodegeneration detected by the areas with demyelination observed initially in the periventricular area and lately in the parenchyma. In conclusion, the presence of cysticerci and the consequent inflammation were able to promote initial periventricular demyelination followed by parenchymatous demyelination as the infection progressed.
\end{abstract}

Keywords: neurocysticercosis; periventricular demyelination; parenchymal demyelination; Taenia crassiceps.

RESUMO

A neurocisticercose (NCC) é classificada como uma doença tropical negligenciada que afeta principalmente a América Latina e a África, apesar de alguns relatos na América do Norte e na Europa. A NCC é responsável por cerca de 30\% dos casos de epilepsia em países endêmicos. Estas lesões parecem ter estreita relação com o estádio de desenvolvimento, com a localização e o número de parasitas, bem como a resposta imune do hospedeiro. $O$ presente estudo objetivou caracterizar a resposta de células inflamatórias e as lesões teciduais pela análise da desmielinização periventricular e parenquimatosa ao longo da infecção experimental de NCC intraventricular. Para tanto, camundongos BALB/c foram submetidos a NCC experimental através da inoculação de cisticercos de Taenia crassiceps. 0 encéfalo foi retirado aos 7, 30, 60 e 90 dias após inoculação (DAl) e analisado após coloração por Hematoxilina e Eosina (HE), Luxol Fast Blue e Nissl. Observou-seventriculomegalia, processo de infiltração inflamatório composto por células polimorfonucleares, mononucleares e macrófagos espumosos. A presença de células inflamatórias foi associada com neurodegeneração, observada pelas áreas de desmielinização que foram inicialmente periventricular e mais tardiamente no parênquima. Em conclusão, observa-se que a presença dos cisticercos e a inflamação foram capazes de promover desmielinização periventricular inicial e parenquimatosa conforme houve progressão tardia da infecção.

Palavras-chave: neurocisticercose; desmielinização periventricular; desmielinização parenquimal;Taenia crassiceps.

Amongst the tropical neglected diseases, neurocysticercosis (NCC) emerges as a parasitic public health infection in regions where pigs roam freely, with clandestine slaughtering and deficient basic sanitation ${ }^{1,2}$. NCC afflicts around 2.5 to 8.3 million people including symptomatic and asymptomatic cases throughout the world ${ }^{2}$. Its prevalence is related to

${ }^{1}$ Universidade Federal de Goiás, Instituto de Patologia Tropical e Saúde Pública, Goiânia GO, Brazil.

²Universidade Federal de Goiás, Programa de Pós-Graduação em Medicina Tropical e Saúde Pública, Instituto de Patologia Tropical e Saúde Pública, Goiânia Go, Brazil. ${ }^{3}$ Universidade de Rio Verde, Faculdade de Medicina, Aparecida de Goiânia GO, Brazil.

«Universidade Federal de Goiás, Faculdade de Medicina, Goiânia GO, Brazil.

Lopes MOURA ID https://orcid.org/0000-0002-0805-7197; Analia Cirqueira MILHOMEM iD https://orcid.org/0000-0001-6264-8695; Sarah Buzaim LIMA ID https://orcid.org/0000-0002-1000-2486; Hidelberto MATOS-SILVA iD https://orcid.org/0000-0003-2306-2864; Denis Masashi SUGITA iD https://orcid.org/0000-0002-8592-7002; Mariana Clare VINAUD iD https://orcid.org/0000-0002-6746-9191; Ruy de Souza LINO-JÚNIOR (iD) https://orcid. org/0000-0002-0572-5102

Correspondence: Ruy de Souza Lino Júnior; Rua 235, s/nº, St. Universitário; 74605-050 Goiânia G0, Brazil; E-mail: ruylino@yahoo.com.br

Conflict of interest: There is no conflict of interest to declare.

Received on March 21, 2019; Received in final form on August 27, 2019; Accepted on September 19, 2019. 
socio-economic cultural factors such as eating and hygienic habits and pig farming in developing countries. On the other hand, the increase in the immigrant population from endemic areas in developed countries is accounted responsible for the expansion in the NCC cases $^{3}$.

The cysticerci promote an influx of inflammatory cells that vary according to the encephalic location of the parasite and to the time of infection starting from the moment they penetrate into the central nervous system. When it reaches the ventricles, an obstruction of the cerebrospinal fluid may occur leading to hydrocephaly, intracranial hypertension, ventricular dilatation, headache, inflammatory reactions, epilepsy, cerebral vascular accident, and radicular compression, presenting or not fibrosis ${ }^{4-6}$.

Experimental models have been useful in the understanding of the complex host-parasite interaction of NCC. Up to the moment, there are five experimental models used in NCC studies: Mesocestoides corti in BALB/c mice ${ }^{7}$, Taenia crassiceps in both BALB/c and C57BL/6 mice $^{8}$, and inoculation of T. solium active oncospheres in rats $^{9}$ and piglets ${ }^{10}$.

The aggregation of parasites and inflammatory cells in extraparenchymal regions, inducing an initial Th1 immune response followed by a Th2 one leading to the final destruction of the parasites in a late stage of the infection, has been reported ${ }^{7,11}$. It has been suggested that the parasites induce a balance with the initial immune response, which is lost due to the shift of the immune profile throughout the infection time leading to the destruction of the parasite $^{12}$. The role of the foamy macrophages is controversial. However, it is believed that they are responsible for the phagocytosis of the destroyed cell membranes, accumulating cholesterol within their cytoplasm, which gives their aspect of foam ${ }^{13}$.

The idiopathic demyelinating inflammatory diseases of the CNS constitute a heterogenous group of injuries, which differ in their clinic course, pathology, and immunopathogenesis. In spite of the wide variety of differences between these diseases, what they present in common is the inflammation of the CNS, demyelination, and varied axonal loss ${ }^{14}$. They may occur in two distinct phases: an initial one characterized by the inflammatory process and a latter one with a progressive neurodegeneration ${ }^{15}$. It has been suggested that the oxidative stress generated by the inflammation may be the cause or at least play an auxiliary role in the pathogenesis of the main neurodegenerative diseases ${ }^{16-19}$. The demyelination may be induced by soluble factors produced by the inflammatory cells, which diffuse through the parenchyma in a direct form or through the microglia activation ${ }^{19,20}$.

Demyelination is widely studied in patients and in experimental models of Multiple Sclerosis (MS), which is an inflammatory demyelinating disease of the CNS and causes synaptic alterations in the hippocampus ${ }^{21}$. It is also described the dual role of nitric oxide ( $\mathrm{NO})^{22}$ leading to the diffuse regional atrophy of the brain ${ }^{23}$. These characteristics in the axonal pathology were experimentally reproduced ${ }^{24}$ showing a heterogenous pathogenesis ${ }^{25}$ and that the cortical demyelination occurs precociously ${ }^{26}$.

Amongst the literature, there are several hypothesis trying to explain the relation between inflammation and demyelination in several neurodegenerative diseases, but not in a parasitic one. Therefore, the aim of this study was to describe the influence of the parasite in the periventricular and parenchymatous demyelination throughout the infection period using the intracranial inoculation of $T$. crassiceps cysticerci, i.e., experimental NCC.

\section{METHODS}

\section{Experimental design}

This study was approved by the Ethics Committee in Animal Use from the Federal University of Goiás (CEUA/ UFG), protocol number 010/11.

The NCC experimental infection was performed using female BALB/c mice from 8 to 12 weeks old $(n=40)$. The use of female mice is indicated because estradiol and progesterone stimulate reproduction and infectivity of the cysticerci. Initial stage $T$. crassiceps cysticerci ${ }^{27}$ were removed from one intraperitoneal infected mouse, washed twice with PBS for posterior intracranial inoculation ${ }^{28}$.

The mice were anesthetized $(0.01 \mathrm{~mL} / \mathrm{g}$ of $2 \%$ Xilazine and $10 \%$ Ketamine); afterwards, the tricotomy of the superior region of the head was performed in order to expose the cranial surface. A longitudinal incision was performed in the skin and subcutaneous tissue, which allowed the visualization of the bone junctions and the bregma point. The cranial perforation was performed with a micromotor (LB100-Beltec) and diamond drill $(44.5 \times 2 \mathrm{~mm})$ according to the stereotaxic coordinates antero-posterior $=-2.0$ and lateral $=+3.0$. Three cysticerci were inoculated in each animal with a $1 \mathrm{~mL}$ syringe with an adapted 25G needle (2 mm length) which enabled to reach the brain ventricles. After the surgical procedures, the incisions were closed with acrylic resin and sutured. The inoculation of $10 \mu$ l of physiologic solution $(\mathrm{NaCl}$ $0.9 \%$ ) was inoculated in the control animals ${ }^{8}$. No animal died after the intracranial inoculation.

The euthanasia of the animals was performed at 7, 30, 60 , and 90 days after the inoculation (DAI) through cervical dislocation. The brains were removed for the histopathologic analysis. Each experimental day was evaluated with five infected animals and five control ones.

\section{Histopathologic analysis}

The removed brains were fixed in $10 \%$ buffered formalin for 24 hours, processed for inclusion in paraffin, sliced in $5 \mu \mathrm{m}$ width, and stained with hematoxylin and eosin (HE). Three serial cuts with $50-\mu \mathrm{m}$ spacing were performed from each animal. 
The pathologic processes analyzed in the brain tissues were: ventriculomegaly, polymorphonuclear cells inflammatory infiltration (PMN), mononuclear cells inflammatory infiltration (MN), foamy macrophages, meningitis, ependimitis, microgliosis (increase in the glial cellularity, especially astrocytic and microglial), and injuries in granular cells (components of the hippocampus). These pathologic processes were classified in a semi-quantitative form as follows: absente, discrete with up to $25 \%$ of area commitment, moderate with 26 to $50 \%$ of area commitment, and accentuated with more than $50 \%$ of area commitment ${ }^{29}$. The ventriculomegaly was analyzed in a semi-quantitative form using the same parameters described above, but using as comparison the contra-lateral non-infected ventricle from the same animal ${ }^{30}$.

\section{Demyelination and axonal injurie analyzes}

The demyelination was evaluated through the Luxol Fast Blue staining technique. The Nissl staining was performed in order to verify the axonal disorganization or injury in demyelinated areas. The demyelination was evaluated in a qualitative and semi-quantitative form according to the following criteria:

- $\quad$ Location - periventricular or parenchymatous.

- Intensity - restricted to the periventricular demyelination cases: absent (score 0), discrete (demyelination sites, score 1 ), moderate (demyelinating areas up to $50 \%$ of the periventricular area, score 2), and accentuated (demyelinating areas greater than $50 \%$ of the periventricular area, score 3 ).

- Distribution - restricted to the parenchymatous demyelinating areas: focal or diffuse. The axonal disorganization was evaluated according to the fibers disposition, lamellar or irradiated, in a descriptive form.

\section{Statistical analysis}

The statistical analysis was performed with the Sigma Stat 3.5 software. All variables were tested as to normal distribution and homogenous variation. The pathologic processes were evaluated through the Mann-Whitney test and Student's t-test, according to the parametric and non-parametric distribution. The demyelination was evaluated through mean and mean standard error. The differences were considered significant when $\mathrm{p} \leq 0.05$.

\section{RESULTS}

All mice from the infected groups presented the cysticerci located within one of the lateral ventricles inducing inflammation, expansion of the ventricular cavity, and, in some cases, deviation of the brain midline. All results obtained after the analyses are described in Table 1 and illustrated in Figures 1, 2, and 3.
At $7 \mathrm{DAI}$, the control group presented MN inflammatory infiltration, microgliosis, and dispersion of the hippocampus cells. In the infected group, it was also observed the presence of MN inflammatory infiltration, but with greater intensity. There was no periventricular nor parenchymatous demyelination in both groups, control and infected. However, the infected group presented axonal disorientation in a parenchymatous inflammation site (Table 1, Figure 1).

At 30 DAI, the alterations observed in the infected group were greater when compared to the ones observed in the control group. It was possible to detect ventriculomegaly in different intensities, mixed moderate inflammatory infiltration, discrete presence of foamy macrophages, discrete meningitis, ependimitis, and hippocampus injury. In the control group, it was possible to observe MN inflammatory infiltration, discrete meningitis, ependimitis, and injury in the hippocampus. In the infected group, the demyelination was discrete in $100 \%$ of the analyzed animals and only $40 \%$ of them presented focal parenchymal demyelination. In addition, one infected animal presented axonal disorganization in a parenchymatous inflammatory focus at $30 \mathrm{DAI}$ (Table 1, Figures 1 and 3).

At $60 \mathrm{DAI}$, the mice from the control group presented MN inflammatory infiltration, discrete ependimitis, and hippocampus injury, while the infected mice presented ventriculomegaly of the lateral ventricle, mixed profile of inflammatory infiltration, discrete presence of foamy macrophages, ependimitis, and injury in the hippocampus cells. In the infected group, the periventricular demyelination was present in $80 \%$ of the animals. The parenchymal demyelination in CA2 and CA3 hippocampus areas was observed in $20 \%$ of the cases in a focal form (Table 1, Figure 3).

At 90 DAI, the infected mice presented discrete intensity of foamy macrophages and microgliosis, ventriculomegaly, mixed profile of inflammatory infiltration, ependimitis, and varied intensity of alterations in the hippocampus cells, while in the control group it was possible to observe discrete intensity of mixed inflammatory infiltration and hippocampus alterations. The periventricular demyelination was observed in $40 \%$ of the analyzed animals and $80 \%$ of them presented focal parenchymal demyelination (Table 1, Figures 1 and 3).

\section{DISCUSSION}

The present study used the NCC experimental model of female BALB/c mice intracranially inoculated with initial stage T. crassiceps cysticerci. This parasite is the most used as T. solium experimental model as they belong to the same genus, presenting antigenic and epitope similarities. They are very rare in human infections, which make its handling very safe. In addition, its capability of asexual reproduction through budding provides a great source of biological material ${ }^{28}$. 
In the initial phase of the infection, it was possible to observe an influx of inflammatory cells. These cells belonging to the glial group of cells are responsible for the normal functioning of the CNS and are able to communicate between themselves, as well as with neurons and vascular cells ${ }^{30}$. Bernardinelli et al. ${ }^{31}$ described that glial cells participate in the maintenance of neurons in homeostasis and when there are alterations, they release $\mathrm{Ca}^{+2}$ leading to neuron

Table 1. Analysis of the general pathologic processes in the brain of female BALB/c mice intracranially inoculated with Taenia crassiceps cysticerci.

\begin{tabular}{|c|c|c|c|c|}
\hline Microscopic alterations & DAI & $\begin{array}{l}\text { Control group }(n=5) \\
\text { median (min-max) }\end{array}$ & $\begin{array}{l}\text { Infected group }(n=5) \\
\text { median (min-max) }\end{array}$ & $\mathrm{p}$-value \\
\hline \multirow{4}{*}{ Ventriculomegaly } & 7 & $0(0-0)$ & $0(0-0)$ & 1.000 \\
\hline & 30 & $0(0-0)$ & $3(1-3)$ & 0.008 \\
\hline & 60 & $0(0-0)$ & $1(0-3)$ & 0.151 \\
\hline & 90 & $0(0-0)$ & $2(1-3)$ & 0.008 \\
\hline \multirow{4}{*}{$\begin{array}{l}\text { PMN inflammatory } \\
\text { infiltration }\end{array}$} & 7 & $0(0-0)$ & $0(0-0)$ & 1.000 \\
\hline & 30 & $0(0-0)$ & $1(1-2)$ & 0.008 \\
\hline & 60 & $0(0-0)$ & $0(0-1)$ & 0.690 \\
\hline & 90 & $0(0-1)$ & $1(0-2)$ & 0.310 \\
\hline \multirow{4}{*}{$\begin{array}{l}\text { MN inflammatory } \\
\text { infiltration }\end{array}$} & 7 & $1(1-1)$ & $0(0-2)$ & 0.690 \\
\hline & 30 & $1(0-1)$ & $2(2-2)$ & 0.008 \\
\hline & 60 & $0(0-1)$ & $1(0-2)$ & 0.151 \\
\hline & 90 & $0(0-1)$ & $2(1-3)$ & 0.008 \\
\hline \multirow{4}{*}{ Foamy macrophages } & 7 & $0(0-0)$ & $0(0-0)$ & 1.000 \\
\hline & 30 & $0(0-0)$ & $1(1-1)$ & 0.008 \\
\hline & 60 & $0(0-0)$ & $0(0-1)$ & 0.310 \\
\hline & 90 & $0(0-0)$ & $1(0-1)$ & 0.032 \\
\hline \multirow{4}{*}{ Meningitis } & 7 & $0(0-0)$ & $0(0-0)$ & 1.000 \\
\hline & 30 & $0(0-1)$ & $0(0-1)$ & 0.690 \\
\hline & 60 & $0(0-0)$ & $0(0-0)$ & 1.000 \\
\hline & 90 & $0(0-0)$ & $1(1-1)$ & 0.008 \\
\hline \multirow{4}{*}{ Ependimitis } & 7 & $0(0-0)$ & $0(0-0)$ & 1.000 \\
\hline & 30 & $0(0-1)$ & $1(0-2)$ & 0.222 \\
\hline & 60 & $0(0-1)$ & $0(0-1)$ & 0.690 \\
\hline & 90 & $0(0-0)$ & $1(0-2)$ & 0.032 \\
\hline \multirow{4}{*}{ Microgliosis } & 7 & $0(0-1)$ & $0(0-0)$ & 0.690 \\
\hline & 30 & $0(0-0)$ & $0(0-0)$ & 1.000 \\
\hline & 60 & $0(0-0)$ & $0(0-0)$ & 1.000 \\
\hline & 90 & $0(0-0)$ & $0(0-1)$ & 0.690 \\
\hline \multirow{4}{*}{$\begin{array}{l}\text { Hippocampus injury } \\
\text { CA2 and CA3 areas }\end{array}$} & 7 & $2(1-2)$ & $1(1-1)$ & 0.151 \\
\hline & 30 & $0(0-2)$ & $2(1-3)$ & 0.095 \\
\hline & 60 & $1(0-2)$ & $2(2-3)$ & 0.032 \\
\hline & 90 & $1(1-2)$ & $2(1-3)$ & 0.548 \\
\hline
\end{tabular}

DAl: days after the inoculation; PMN: polymorphonuclear cells; MN: mononuclear cells; CA: Cornu Ammonis; bold: statistical difference performed by the MannWhitney test. 
death through deficiency in glucose uptake and catabolism. Our results corroborate with this description because it was possible to observe glial cell alterations in both groups, control and infected, probably due to the reception of stimuli, which provoked morphology changes, and acquisition of new phagocytic effector functions capable of inducing
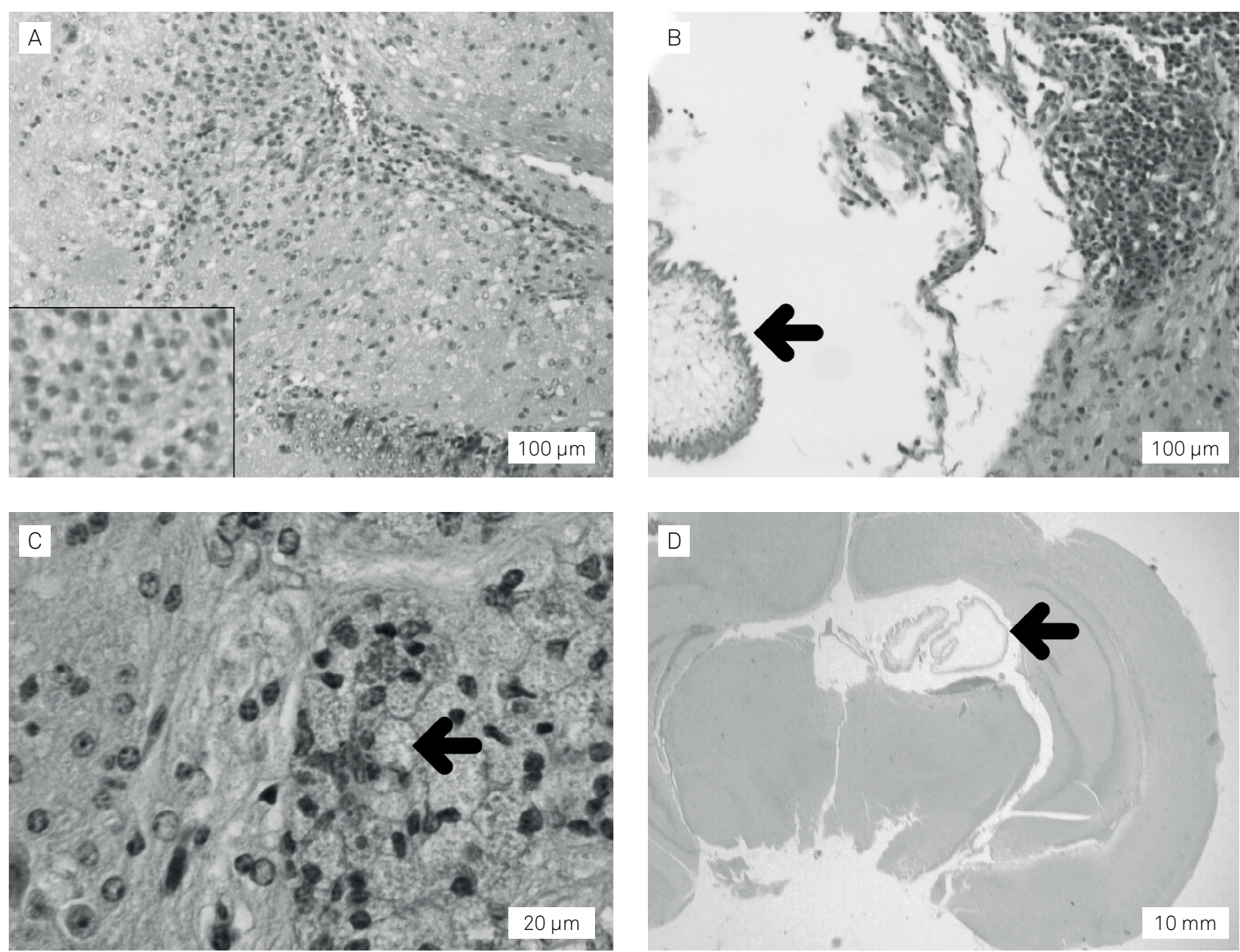

Figure 1. Photomicrograph of the brain of mice infected with Taenia crassiceps cysticerci and control groups, intracranially inoculated with saline physiologic solution ( $\mathrm{NaCl}$ 0.9\%). (A) microgliosis (insert) in control group 7 days after the inoculation (DAl), scale $100 \mu \mathrm{m}$. (B) presence of cysticercus (arrow) surrounded by inflammatory process in the ventricle, $30 \mathrm{DAl}$, scale: $100 \mu \mathrm{m}$. (C) presence of foamy macrophages (arrow) in infected animals 90 DAl, scale $20 \mu \mathrm{m}$. (D) ventriculomegaly and presence of cysticercus (arrow), $90 \mathrm{DAl}$, scale: $10 \mu \mathrm{m}$. Staining: H\&E.

Parenchymatous demyelination

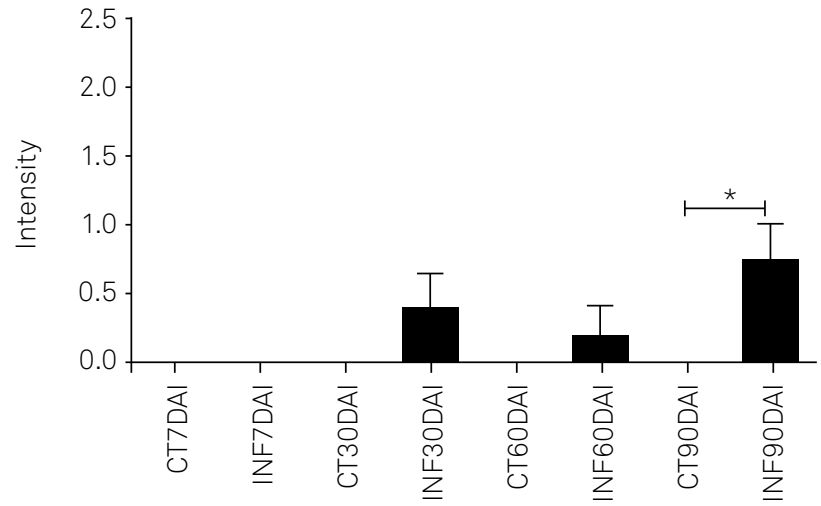

Periventricular demyelination

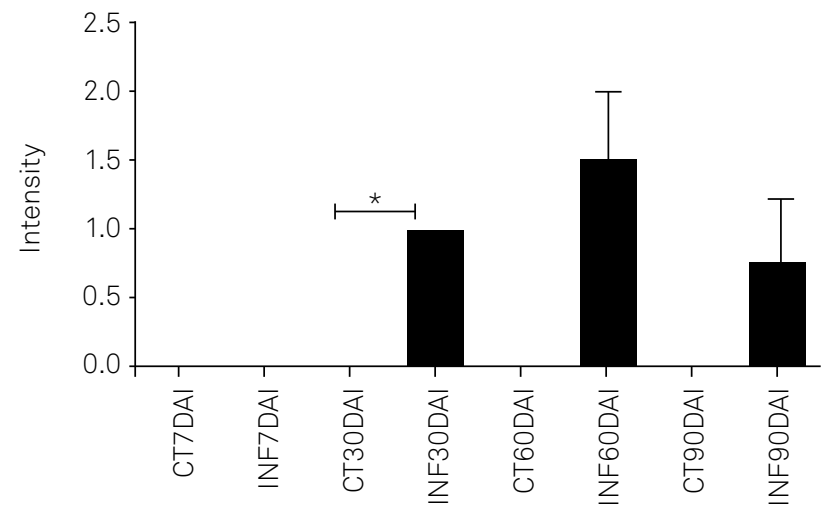

Figure 2. Comparison of the intensity of periventricular and parenchymatous demyelination in Taenia crassiceps intracranially infected mice and the control group inoculated with saline physiologic solution ( $\mathrm{NaCl} 0.9 \%$ ). The results are expressed in mean and mean standard error of the scores as follows: absent — score 0; discrete — score 1; moderate - score 2; accentuated score 3. *: statistical difference. CT: control group, INF: infected group, DAl: days after the inoculation. 
inflammation and contributing to the disease pathogenesis ${ }^{32}$. Matos-Silva et al. ${ }^{8}$ observed that at 7 days of neuro-infection with T. crassiceps in BALB/c mice it was possible to observe gliosis, edema, hyperemia, ependimitis, perivasculitis, and
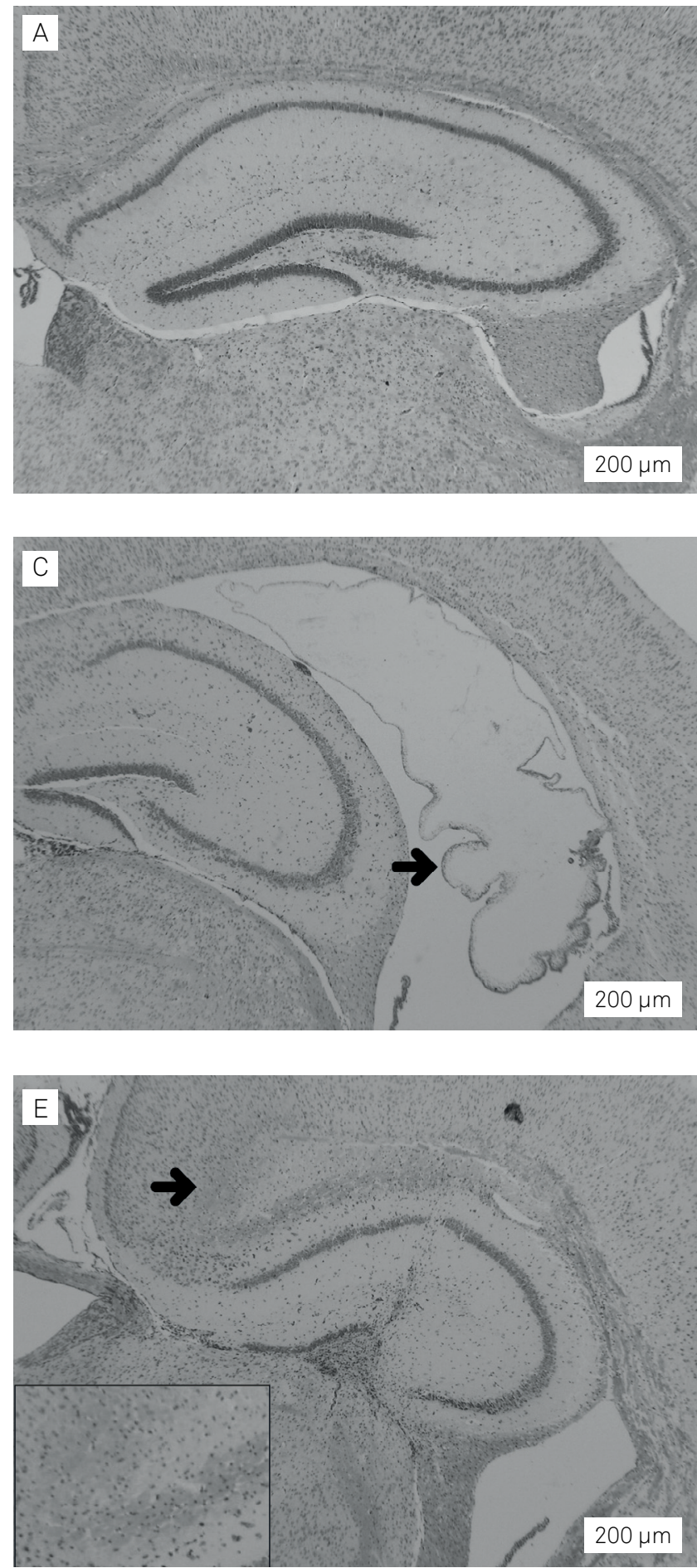

inflammatory infiltration of polymorphonuclear cells and mononuclear cells, all in discrete intensity. Additionally, the analysis of another experimental model of neurocysticercosis using Mesocestoides corti in BALB/c mice indicated that after
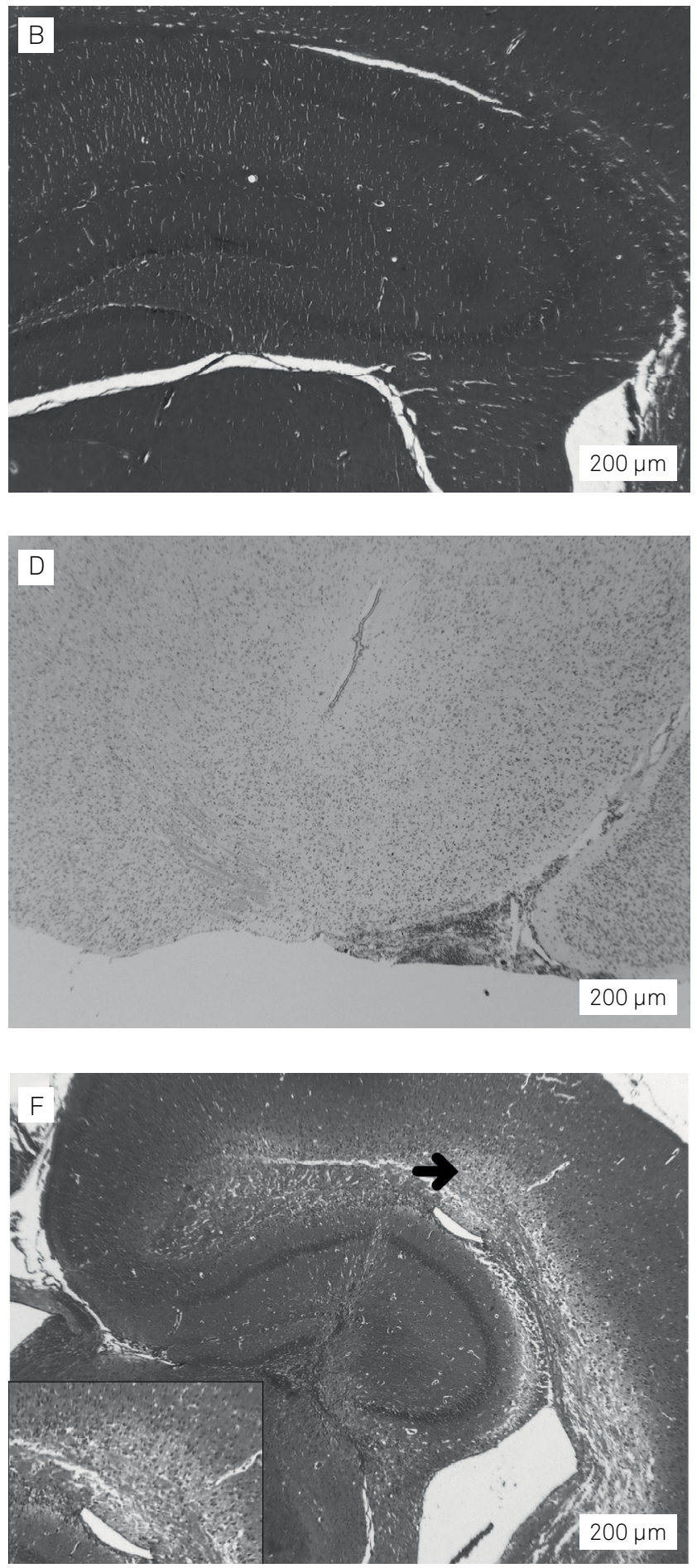

Figure 3. Photomicrograph of brains from mice intracranially infected with Taenia crassiceps cysticerci and control groups, intracranially inoculated with saline physiologic solution ( $\mathrm{NaCl}$ 0.9\%), stained with Luxol Fast Blue and Nissl. (A) normal pattern of myelination in laminar form, control group, 60 days after the inoculation (DAI), Luxol Fast Blue stain. (B) normal pattern of axons, control group, $90 \mathrm{DAl}$, Nissl stain. (C) accentuated ventriculomegaly due to the mass effect and presence of cysticercus (arrow) in Cornu Ammonis areas (CA2 and CA3) of the hippocampus, causing ischemia and adjacent parenchymal demyelination, 90 DAl, Luxol Fast Blue stain. (D) parenchymatous demyelination in pyramidal hippocampus area due to inflammatory focus, 90 DAl, Luxol Fast Blue stain. (E) demyelinating area (arrow and insert) associated to loss of hippocampus cells, 60 DAl, Luxol Fast Blue stain. (F) irradiated axon pattern (arrow and insert) next to the inflammatory process, 60 DAI, Nissl stain. Scale: $200 \mu m$. 
two days of infection it is possible to detect an inflammatory infiltration of macrophages, neutrophils, $\gamma \delta \mathrm{T}$ cells, and NK cells in the cerebral parenchyma. In addition, the presence of parasite's antigens throughout the parenchyma lead to disseminated encephalitis?

At $30 \mathrm{DAI}$, the cysticerci presence within the ventricles, leading to ventriculomegaly and ependimitis, was probably the cause of the local inflammatory process, allowing the influx of mixed profile of inflammatory cells. Among these cells, it was possible to observe foamy macrophages, which accumulate cholesterol, and its esters derived from cell debris and the parasite itself. The inclusion of lipids bodies in immune cells has been recognized as fundamental, as they are important organelles responsible for lipids metabolism, trafficking, and signaling. They present the enzymatic arsenal associated to conversion of arachidonic acid into eicosanoids. They are also responsible for the production of cytokines such as Interleukin-1 (IL-1), IL-6, IL-8, IL-12, IL-10, tumoral necrosis factor-alpha (TNF- $\alpha$ ), and transforming growth factor beta (TGF- $\beta)^{32}$. In addition, gliosis has been linked to the presence of foamy macrophages in infections and inflammatory diseases of the central nervous system ${ }^{33}$.

After the implantation of the parasite in the CNS, several mechanisms are initially observed such as the blocking and inhibition of complement activation through taeniastatin and paramyosin, degradation of immunoglobulins, altering cytokine production, i.e., decreasing IL-1 and IL2, and increasing IL-10 and IL-4. Therefore, it is possible to observe the inhibition of the Th1 immune profile which is replaced by $T h 2^{24,35}$. The parasite's tegument is composed by glycoconjugates with high antigenic variability, enabling the immune evasion because they are dynamically responsive to the alterations in the hosts microenvironment, favoring the presence of alternatively activated macrophages (AAMo or M2), which enable the parasite's proliferation ${ }^{34-38}$. At this point, the parasite has established the ideal survival environment, which is seen in our results in the latter phase of the infection, during which it was possible to observe a predominance of $\mathrm{MN}$ cells in the inflammatory infiltration, characteristic of the Th2 profile.

Helminths are uncapable of lipid synthesis and therefore must acquire it exogenously. After the lipid absorption, it is incorporated into the parasite's tegument and cell membranes $^{34}$. The lipidic corpuscles within macrophages are related to several inflammatory conditions and may function as storage sites and for the synthesis of inflammatory mediators ${ }^{32}$. On the other hand, the first line of defense against microorganism composed by PMN cells are attracted to the infection site and produce chemokines when activated, attracting other immune cells ${ }^{33,36}$. This local inflammation may have been the cause of the periventricular and parenchymatous demyelination observed in our results. This is in accordance to the literature reports that show that inflammatory mechanism and the oxidative stress generated by the inflammation are the cause or an auxiliary factor in the pathogenesis of the main neurodegenerative diseases ${ }^{16-18}$. However, this is the first description of this pathogenic effect in the NCC process.

Most of the cases of demyelination observed in our results were focal and parenchymatous, while only $40 \%$ were periventricular. These results corroborate with other studies, which reported that demyelination might be a consequence of a local inflammatory process ${ }^{26}$. This is the first description of this process in experimental NCC. Lin et al..$^{39}$ confirmed the destruction of the myelin sheath induced by a local inflammatory process related to the presence of a parasite, Angiostrongylus cantonensis. Also, the maintenance of the NCC inflammatory process has direct relation to the increase in the expression of VEGF (vascular endothelial growth factor), which facilitates the influx of immune cells ${ }^{9,10}$.

The role of the inflammatory cells in the tissue injury has been studied in several other diseases ${ }^{13-26}$. However, this role in the neuroinflammation and demyelination in NCC is still an enigma. The experimental models for NCC have contributed to unveil part of this process. Cardona et al. ${ }^{7}$ have described the initial immune response and the predominance of the Th1 profile with $\mathrm{T} \gamma \delta$ (gama delta) lymphocites. Other authors described the inflammatory profile composed by mononuclear cells, $\mathrm{T}$ lymphocytes, plasmocytes, macrophages, and eosinophils at late stages of the infection ${ }^{8-10}$. These data corroborate with our results, in which was also possible to observer MN cell inflammatory infiltration at a later stage of infection. One of the probable causes of the demyelination observed after $30 \mathrm{DAI}$ is the presence of $\mathrm{T} \gamma \delta$ lymphocites throughout the experimental infection, which induced an increase in the pro-inflammatory cytokines production and greater local cellular immune response $e^{7,12}$.

An experimental study described the infection of mice with Trichobilharzia regent (Schistosomatidae) and the histologic and immunohistochemical consequences of this infection. The authors described the axon injuries and demyelination to mechanical injury caused by the parasite's migration through the nervous tissue and not to the host's immune response $\mathrm{e}^{40}$, while the experimental neurological infection with Angiostrongylus cantonensis (Strongylida) induces the release of inflammatory mediators, leading to intracerebral myelin breakdown, and increase in myelin proteins in the cerebrospinal fluid ${ }^{39}$.

The proper understanding of the neuroinflammation / neurodegeneration / demyelination cycle may help in the treatment of several neurodegenerative diseases, improving the clinical symptoms caused by the neuronal loss. The mechanism by which the immune response reacts to several different stimuli is still being clarified. The study and understanding of the multiple factors of the teniasis/cysticercosis complex and the role of inflammatory cells in CNS may help in its treatment, improving symptoms related to neuron injury. 
In our study, little alterations were observed in histopathologic analyzes of the control groups. The surgical procedure promoted the brain blood barrier (BBB), allowing the initial influx of inflammatory cells leading to the hippocampus alterations observed in the late phase of infection. When the BBB integrity is lost, there is an overflow of molecules and cells, which may help to understand some of the mechanisms involved in the cell activation in $\mathrm{NCC}^{30}$.
In conclusion, the experimental model of NCC used in this study was able to demonstrate ventriculomegaly and periventricular demyelination at $30 \mathrm{DAI}$, probably due to the inflammatory process. In the late phase of the infection, it was possible to observe the chronic inflammatory process and the mass effect causing ventricle distension, ependimitis, meningitis, and glial and hippocampus alterations. This is the first description of parenchymatous demyelination in an experimental model of NCC.

\section{References}

1. Laranjo-González M, Devleesschauwer B, Trevisan C, Allepuz A, Sotiraki S, Abraham A, et al. Epidemiology of taeniosis/cysticercosis in Europe, a systematic review: Western Europe. Parasit Vectors. 2017 Jul;10(1):349. https://doi.org/10.1186/s13071-017-2280-8

2. WHO. World Health Organization. Developing surveillance indicators to measure global progress against pork tapeworm [Internet]. Available from: 〈http://www.who.int/taeniasis/en/〉

3. Tellez-Zenteno JF, Hernandez-Ronquillo L. Epidemiology of neurocysticercosis and epilepsy, is everything described? Epilepsy Behav. 2017 Nov;76:143-50. https://doi.org/10.1016/j. yebeh.2017.01.030

4. Fleury A, Cardenas G, Adalid-Peralta L, Fragoso G, Sciutto E. Immunopathology in Taenia solium neurocysticercosis. Parasite Immunol. 2016 Mar;38(3):147-57. https://doi.org/10.1111/pim.12299

5. Sotelo J, Del Brutto $\mathrm{OH}$. Review of neurocysticercosis. Neurosurg Focus. 2002;12(6):1-6. https://doi.org/10.3171/foc.2002.12.6.2

6. Benedeti MR, Falavigna DLM, Falavigna-Guilherme AL, Araújo SM. Perfil clínico-epidemiológico de pacientes com NCC atendidos no Hospital Universitário Regional de Maringá, Paraná, Brasil. Arq Neuropsiquiatr. 2007;65(1):124-9. http://dx.doi.org/10.1590/S0004$282 \times 2007000100025$

7. Cardona AE, Restrepo BI, Jaramillo JM, Teale JM. Development of an animal model for neurocysticercosis: immune response in the central nervous system is characterized by a predominance of gamma delta T cells. J. Immunol. 1999 Jan;162(2):995-1002.

8. Matos-Silva H, Reciputti BP, Paula EC, Oliveira AL, Moura VB, Vinaud MC, et al. Experimental encephalitis caused by Taenia crassiceps cysticerci in mice. Arq Neuropsiquiatr. 2012 Apr;70(4):287-92. https:// doi.org/10.1590/s0004-282×2012005000010

9. Verastegui MR, Mejia A, Clark T, Gavidia CM, Mamani J, Ccopa F, et al. Novel Rat Model for Neurocysticercosis Using Taenia solium. Am J Pathol. 2015 Aug;185(8):2259-68. https://doi.org/10.1016/j. ajpath.2015.04.015

10. Fleury A, Trejo A, Cisneros H, García-Navarrete R, Villalobos N, Hernández M, et al. Taenia solium: development of an experimental model of porcine neurocysticercosis. PLoS Negl Trop Dis. 2015 Aug;9(8):e0003980. https://doi.org/10.1371/journal.pntd.0003980

11. Sciutto E, Chavarria A, Fragoso G, Fleury A, Larralde C. The immune response in Taenia solium cysticercosis: protection and injury. Parasite Immunol. 2007 Dec;29(12):621-36. https://doi.org/10.1111/ j.1365-3024.2007.00967.x

12. Terrazas LI, Bojalil R, Govezensky T, Larralde C. Shift from an early protective Th1-type immune response to a late permissive Th2-type response in murine cysticercosis (Taenia crassiceps). J Parasitol. 1998 Feb;84(1):74-81.

13. Song L, Leung C, Schindler C. Lymphocytes are important in early atherosclerosis. J Clin Invest. 2001 Jul;108(2):251-59. https://doi. org/10.1172/JCl11380

14. Lassmann H. Multiple sclerosis: is there neurodegeneration independent from inflammation? J Neurol Sci. 2007 Aug;259(1-2):3-6. https://doi.org/10.1016/j.jns.2006.08.016
15. Steinman L. Multiple sclerosis: a two-stage diseases. Nat Immunol. 2001 Sep;2(9):762-4. https://doi.org/10.1038/ni0901-762

16. Uttara B, Singh AV, Zamboni P, Mahajan RT. Oxidative Stress and Neurodegenerative Diseases: A Review of Upstream and Downstream Antioxidant Therapeutic Options. Curr Neuropharmacol. 2009 Mar;7(1):65-74. https://doi.org/10.2174/157015909787602823

17. Ferretti $G$, Bacchetti T. Peroxidation of lipoproteins in multiple sclerosis. J Neurol Sci. 2011 Dec;311(1-2):92-7. https://doi. org/10.1016/j.jns.2011.09.004

18. Oliveira SR, Kallaur AP, Simão AN, Morimoto HK, Lopes J, Panis C, et al. Oxidative stress in multiple sclerosis patients in clinical remission: association with the expanded disability status scale. J Neurol Sci. 2012 Oct;321(1-2):49-53. https://doi.org/10.1016/j.jns.2012.07.045

19. Ohno N, Ikenaka K. Axonal and neuronal degeneration in myelin diseases. Neurosci Res. 2019 Feb;139:48-57. https://doi. org/10.1016/j.neures.2018.08.013

20. Lassmann $\mathrm{H}$, Lucchinetti CF. Cortical demyelination in CNS inflammatory demyelinating diseases. Neurology. 2008 Jan;70(5):33233. https://doi.org/10.1212/01.wnl.0000298724.89870.d1

21. Dutta R, Chang A, Doud MK, Kidd GJ, Ribaudo MV, Young EA, et al. Demyelination causes synaptic alterations in hippocampi from multiple sclerosis patients. Ann Neurol. 2011 Mar;69(3):445-54. https://doi.org/10.1002/ana.22337

22. Smith KJ, Lassmann $\mathrm{H}$. The role of nitric oxide in multiple sclerosis. Lancet Neurol. 2002 Aug;1(4):232-41.

23. Haider L, Zrzavy T, Hametner S, Höftberger R, Bagnato F, Grabner G, et al. The topography of demyelination and neurodegeneration in the multiple sclerosis brain. Brain. 2016 Mar;139(Pt 3):807-15. https:// doi.org/10.1093/brain/awv398

24. Kornek B, Storch MK, Weissert R, Wallstroem E, Stefferl A, Olsson T, et al. Multiple sclerosis and chronic autoimmune encephalomyelitis: a comparative quantitative study of axonal injury in active, inactive, and remyelinated lesions. Am J Pathol. 2000 Jul;157(1):267-76. https://doi.org/10.1016/S0002-9440(10)64537-3

25. Lassmann H, Brück W, Lucchinetti C. Heterogeneity of multiple sclerosis pathogenesis: implications for diagnosis and therapy. Trends Mol Med. 2001 Mar;7(3):115-21.

26. Lucchinetti CF, Popescu BF, Bunyan RF, Moll NM, Roemer SF, Lassmann $\mathrm{H}$, et al. Inflammatory cortical demyelination in early multiple sclerosis. N Engl J Med. 2011 Dec;365(23):2188-97. https:// doi.org/10.1056/NEJMoa1100648

27. Vinaud MC, Lino R de S Jr, Bezerra JC. Taenia crassiceps organic acids detected in cysticerci. Exp Parasitol. 2007 Aug;116(4):335-9. https:// doi.org/10.1016/j.exppara.2007.01.013

28. de Lange A, Mahanty S, Raimondo JV. Model systems for investigating disease processes in neurocysticercosis. Parasitology. 2019 Apr;146(5):553-62. https://doi.org/10.1017/S0031182018001932

29. Lino Junior RS, Ribeiro PM, Antonelli EJ, Faleiros ACG, Terra AS, Reis MA, et al. Características evolutivas do Cysticercus cellulosae no encéfalo e no coração humanos. Rev Soc Bras Med Trop 2002 Nov-Dec;35(6):617-22. http://dx.doi.org/10.1590/S0037-86822002000600012 
30. Shook BA, Lennington JB, Acabchuk RL, Halling M, Sun Y, Peters J, et al. Ventriculomegaly associated with ependymal gliosis and declines in barrier integrity in the aging of human and mouse brain. Aging Cell. 2014 Apr;13(2):340-350. https://doi.org/10.1111/acel.12184

31. Bernardinelli Y, Magistretti PJ, Chatton JY. Astrocytes generate $\mathrm{Na}+$ mediated metabolic waves. Proc Natl Acad Sci U S A. 2004 Oct;101(41):14937-42. https://doi.org/10.1073/pnas.0405315101

32. Melo RC, Dvorak AM. Lipid body-phagosome interaction in macrophages during infectious diseases: host defense or pathogen survival strategy PLoS Pathog. 2012;8(7):e1002729. https://doi. org/10.1371/journal.ppat.1002729

33. Psachoulia K, Chamberlain KA, Heo D, Davis SE, Paskus JD, Nanescu SE, Huang JK. IL4I1 augments CNS remyelination and axonal protection by modulating T cell driven inflammation. Brain. 2016;139(12):3121-36. https://doi.org/10.1093/brain/aww254

34. Maizels RM, Bundy DA, Selkirk ME, Smith DF, Anderson RM. Immunological modulation and evasion by helminth parasites in human populations. Nature. 1993 Oct; 365(6449):797-805. https:// doi.org/10.1038/365797a0

35. Gonzales I, Rivera JT, Garcia HH, Cysticercosis Working Group in Peru. Pathogenesis of Taenia solium taeniasis and cysticercosis. Parasite Immunol. 2016 Mar;38(3):136-46. https://doi.org/10.1111/pim.12307
36. Rodriguez-Sosa M, David JR, Bojalil R, Satoskar AR, Terrazas LI. Cutting edge: susceptibility to the larval stage of the helminth parasite Taenia crassiceps is mediated by Th2 response induced via STAT6 signaling. J Immunol. 2002 Apr;168(7):3135-9. https://doi. org/10.4049/jimmunol.168.7.3135

37. Toenjes SA, Spolski RJ, Mooney KA, Kuhn RE. The systemic immune response of BALB/c mice infected with larval Taenia crassiceps is a mixed Th1/Th2-type response. Parasitology. 1999 Jun;118(Pt 6):623-33. https://doi.org/10.1017/ s0031182099004370

38. White AC Jr, Robinson P, Kuhn R. Taenia solium cysticercosis: hostparasite interactions and the immune response. Chem Immunol. 1997;66:209-230.

39. Lin KY, Chen KM, Lan KP, Lee HH, Lai SC. Alterations of myelin proteins in inflammatory demyelination of BALB/c mice caused by Angiostrongylus cantonensis. Vet Parasitol. 2010 Jul;171(1-2):74-80. https://doi.org/10.1016/j.vetpar.2010.03.019

40. Lichtenbergová L1, Lassmann H, Jones MK, Kolářová L, Horák P. Trichobilharzia regenti: host immune response in the pathogenesis of neuroinfection in mice. Exp Parasitol. 2011 Aug;128(4):328-35. https://doi.org/10.1016/j. exppara.2011.04.006 